\title{
Effect of transient accumulation of anthocyanin on leaf development and photoprotection of Fagopyrum dibotrys mutant
}

\author{
J.-X. LAN, A.-L. LI* and C.-X. CHEN \\ The Institute of Medicinal Plant Development, Chinese Academy of Medical Sciences, \\ Peking Union Medical College, 100193, Beijing, P.R. China
}

\begin{abstract}
Changes in pigments contents, leaf area, leaf dry mass per unit area (LMA), photosynthetic rate and chlorophyll $a$ fluorescence were investigated in developing leaves of Fagopyrum dibotrys Hara. mutant. Anthocyanins transiently accumulate below the upper epidermis during leaf ontogeny of this mutant. Red leaves possessed lower Chl content, LMA, photosynthetic rate and apparent carboxylation efficiency than green leaves. However, content of anthocyanins declined and above mentioned parameters increased during further leaf development. In both red and green leaves, chronic photoinhibition did not take place according to variable to maximum chlorophyll fluorescence ratio $\left(\mathrm{F}_{\mathrm{v}} / \mathrm{F}_{\mathrm{m}}\right)$. Red leaves had higher non-photochemical quenching (NPQ) and higher PS 2 efficiency.
\end{abstract}

Additional key words: chlorophyll fluorescence, green and red leaves, net photosynthetic rate, PS 2 efficiency.

The juvenile stage of leaf development is the most vulnerable time in the life cycle of a leaf, and anthocyanin accumulation is often present during this stage (Coley and Kursar 1996, Numata et al. 2004). The appearance of anthocyanins in leaf tissue is also correlated to stresses such as low temperature in combination with excessive sunlight (Krol et al. 1995, Janda et al. 1996), UV-B radiation (Ravindran et al. 2001, Ambasht and Agrawal 2003), pathogen infection (Hipskind et al. 1996), nutrient deficiency (Ulrychová and Sosnová 1970, Kumar and Sharma 1999), herbivore feeding (Kursar and Coley 1992, Dominy et al. 2002), and general injury (Stone et al. 2001). During protection against such stresses, the anthocyanins can act as antioxidants (Chalker-Scott 1999) and/or as signal that a plant is undergoing stress. The role of anthocyanin pigments during leaf development is photoprotection since red pigments typically accumulate either on one leaf surface or on both, subsequently masking green chlorophyll (Chl) reflectance or assisting red light absorption (Pomar and Barceló 2007). Red leaves absorb from blue to green to yellow radiation (Hughes and Smith 2007). For example, anthocyanins located within the epidermis of jack pine has been found to reduce its sensitivity to photoinhibition at low temperatures by means of radiation attenuation (Krol et al. 1995) and reduced risk of photo-oxidative damage to leaf tissue by masking Chl (Feild et al. 2001). In addition, anthocyanins in Cistus creticus act as a radiation screen and/or antioxidants (Kytridis et al. 2008).

Anthocyanin accumulation may also affect other pigment biosynthesis due to the carbon skeleton cost and photosynthesis due to competition between anthocyanins and $\mathrm{Chl}$ to capture radiation. Red leaves have been

Received 15 January 2010, accepted 11 January 2011.

Abbreviations: Chl - chlorophyll; $\mathrm{F}_{\mathrm{m}}$ - maximum fluorescence of dark-adapted leaves; $\mathrm{F}_{\mathrm{m}}{ }^{\prime}$ - maximum fluorescence of light-adapted leaves; $\mathrm{F}_{0}$ - minimum fluorescence of dark-adapted leaves; $\mathrm{F}_{0}{ }^{\prime}$ - minimum fluorescence of light-adapted leaves; $\mathrm{F}_{\mathrm{v}} / \mathrm{F}_{\mathrm{m}}-\mathrm{variable}$ to maximum fluorescence ratio (efficiency of PS 2); $\Delta \mathrm{F} / \mathrm{F}_{\mathrm{m}}{ }^{\prime}$ - PS 2 photochemical efficiency in the light-adapted state; LMA - leaf dry mass per unit area; NPQ - non-photochemical quenching; PAR - photosynthetically active radiation; $\mathrm{P}_{\mathrm{N}}$ - net photosynthetic rate; $\mathrm{P}_{\mathrm{Nmax}}$ - light saturated $\mathrm{P}_{\mathrm{N}}$; PS 2 - photosystem 2.

Acknowledgements: We are grateful to China Postdoctoral Science Foundation (No. 20090450326).

* Corresponding author: fax: (+86) 010 62896810; e-mail: alli@implad.ac.cn 
reported to possess lower $\mathrm{CO}_{2}$ assimilation and $\mathrm{Chl} a / b$ ratios, and they are generally thinner than green leaves (Manetas et al. 2003, Kyparissis et al. 2007). The maximum photosynthetic rate of red leaves was usually lower compared to green leaves (Lambers et al. 1998).

With the aim to clarify the photoprotective function of anthocyanins, an array of morphologic and photosynthetic parameters was investigated in Fagopyrum dibotrys mutant over-accumulating anthocyanins during leaf development.

The Fagopyrum dibotrys Hara. is perennial buckwheat, and the rhizomes have been utilized for medicinal purposes in China, Thailand and Nepal. F. dibotrys mutant was introduced by means of $\gamma \mathrm{Co}^{60}$ irradiation in 2007 and was utilized from the M2 generation. Experiments were carried out from April to June, 2009, at the research station of the Institute of Medicinal Plant Development (lat $39^{\circ} 47^{\prime} \mathrm{N}$, long. $116^{\circ} 25^{\prime} \mathrm{E}$, alt. $50 \mathrm{~m}$ ), located in a temperate continental climatic region. $F$. dibotrys roots were cut into approximately $3 \mathrm{~cm}$ long pieces having no more than three sprouts and planted in the greenhouse for approximately $14 \mathrm{~d}$ until the third leaf of each individual plant sprouted. Seedlings were then transplanted into fields. Red pigments accumulated on the abaxial leaves of the $F$. dibotrys mutant while the original (control) plant remained green. The seedlings were approximately $10 \mathrm{~cm}$ in height $15 \mathrm{~d}$ after transplantation and the leaves of the mutant turned green except for third or fourth apex leaves after three weeks. Three to ten leaves were chosen from control and mutant plants at 15-d intervals until the visible anthocyanins could not be seen by the naked eye. Leaf pigments contents, leaf area, leaf dry mass, net photosynthetic rate, photosystem 2 (PS 2) efficiency, and non-photochemical quenching (NPQ) were examined in 10, 25, 40 and 55-d-old plants.

Leaves were cut into 50 to $100 \mu \mathrm{m}$ sections by vibratome (Leica CM1900, Leica Microsystems, Bannockburn, IL, USA). The sections were then mounted on a Zeiss Axio Imager Al microscope (Carl Zeiss, Thornwood, NY, USA). Leaf thickness was measured using AxioVision software. Leaf area was analyzed using the AM300 portable leaf area meter (ADC BioScientific, Hoddesdon, UK). Anthocyanins were extracted in plastic vials containing $5 \mathrm{~cm}^{3} \mathrm{HCl}: \mathrm{H}_{2} \mathrm{O}: \mathrm{MeOH}(1: 23: 79)$ in the dark for $24 \mathrm{~h}$ at $4{ }^{\circ} \mathrm{C}$. Anthocyanin content was determined spectrophotometrically (UV 2550, Shimadzu, Tokyo, Japan) as $\mathrm{A}_{530}-0.24 \mathrm{~A}_{653}$ (Murray and Hackett 1991). Chl were extracted in $80 \%$ acetone. Chl content was determined by measuring $\mathrm{A}_{663}$ and $\mathrm{A}_{646} \mathrm{~nm}$ and calculated according to Lichtenthaler (1987). For determination of leaf dry mass per unit area (LMA) selected leaf samples were dried at $80{ }^{\circ} \mathrm{C}$ for $24 \mathrm{~h}$.

The light response curves were measured by $L I-6400$ open photosynthesis system (LI-COR, Lincoln, NE, USA) fitted with a red-blue LED light source and a $\mathrm{CO}_{2}$ mixer on 40 and 55-d-old plants. Data were collected between 08:00 and 11:30. Temperature and relative air humidity inside the chamber were $30 \pm 4{ }^{\circ} \mathrm{C}$ and $30 \pm 5 \%$, respectively, $\mathrm{CO}_{2}$ concentration about $400 \mu \mathrm{mol} \mathrm{mol}{ }^{-1}$, and irradiance was greater than $1500 \mu \mathrm{mol} \mathrm{m} \mathrm{m}^{-2} \mathrm{~s}^{-1}$. Prior to measurement, plant samples were allowed to fully adapt for $30 \mathrm{~min}$ inside the leaf chamber to activate leaf conductance. The maximum photosynthetic rate $\left(\mathrm{P}_{\mathrm{Nmax}}\right)$ was computed according to the equation by Prado and Moraes (1997).

Chlorophyll $a$ fluorescence was determined on the third fully exposed leaves from the apex using the LI-6400 system fitted with a 6400-40 leaf chamber fluorometer. Variable to maximum fluorescence ratio $\left(\mathrm{F}_{\mathrm{v}} / \mathrm{F}_{\mathrm{m}}\right)$ was measured in the predawn and calculated as $\left(F_{m}-F_{0}\right) / F_{m}$ (Maxwell and Johnson 2000). Minimum fluorescence $\left(\mathrm{F}_{0}\right)$ was determined under dim light $\left(<0.5 \mu \mathrm{mol} \mathrm{m} \mathrm{m}^{-2} \mathrm{~s}^{-1}\right)$ after $15 \mathrm{~min}$ of dark adaptation. A saturating flash of $6000 \mu \mathrm{mol} \mathrm{m} \mathrm{m}^{-2} \mathrm{~s}^{-1}$ of $0.8 \mathrm{~s}$ duration was used to determine maximum fluorescence $\left(F_{m}\right)$. Leaves were kept in a chamber with approximately $1800 \mu \mathrm{mol} \mathrm{m} \mathrm{m}^{-2} \mathrm{~s}^{-1}$ actinic light for determination of $\mathrm{F}_{0}{ }^{\prime}$ and $F_{m}{ }^{\prime}$ during a period between 08:00 and 13:30. PAR was reprogrammed after every cycle and lowered from 1800 to $0 \mu \mathrm{mol} \mathrm{m} \mathrm{m}^{-2} \mathrm{~s}^{-1}$. A saturation flash of $6000 \mu \mathrm{mol} \mathrm{m} \mathrm{m}^{-2} \mathrm{~s}^{-1}$ for $0.8 \mathrm{~s}$ was provided to obtain $\mathrm{F}_{\mathrm{m}}{ }^{\prime}$ of light-adapted leaf. $\mathrm{F}_{0}^{\prime}$ was measured after gradually reducing irradiance and using the far-red (FR) of $7 \mu \mathrm{mol}$ $\mathrm{m}^{-2} \mathrm{~s}^{-1}$ for $0.6 \mathrm{~s}$. The experiments were continued in steps using the same cycle of flashes and FR irradiation for 4 min intervals. The PS 2 photochemical efficiency in the light-adapted state was calculated according to Genty (1989) as $\Delta \mathrm{F} / \mathrm{F}_{\mathrm{m}}{ }^{\prime}=\left(\mathrm{F}_{\mathrm{m}}{ }^{\prime}-\mathrm{F}_{0}{ }^{\prime}\right) / \mathrm{F}_{\mathrm{m}}{ }^{\prime}$ and NPQ was calculated according to Bilger and Björkman (1990) as $\mathrm{NPQ}=\left(\mathrm{F}_{\mathrm{m}}-\mathrm{F}_{\mathrm{m}}{ }^{\prime}\right) / \mathrm{F}_{\mathrm{m}}{ }^{\prime}$.

One-way $A N O V A$ was carried out to analyze the significance of differences among treatment group means for the measured parameters (Systat Software, Chicago, IL, USA).

The lower epidermis and mesophyll cell layer of the red leaves exhibited reddening after transplantation. The upper epidermis remained green during this period. Slight anthocyanin accumulations were observed within the veins of green leaves (data not shown). Red leaf anthocyanin accumulation remained visible to the naked eye for approximately $60 \mathrm{~d}$, and the veins of green leaves maintained a pale red color throughout the experimental period. Red leaves contained considerably more anthocyanins than green leaves $(P<0.01)$ at every stage (Table 1). Anthocyanin accumulation in red leaves was three times higher than in green leaves during the first stage. Thereafter the red coloring in leaves became invisible to the naked eye, even red leaves had approximately $23 \%$ higher anthocyanins accumulation than green leaves.

Leaf area and thickness increased gradually during growth periods (Table 1), indicating that they were enlarging as they progressed from young to mature states. 


\section{J.-X. LAN et al.}

Table 1. Anthocyanin content $(n=6-10)$, the leaf area $(n=6-10)$, leaf thickness $(n=10)$, LMA $(n=10)$, chlorophyll content and Chl $a / b$ ratio $(n=5)$, maximum photosynthetic rate $\left(\mathrm{P}_{\mathrm{Nmax}}\right)(n=6)$, apparent carboxylation efficiency $\left(\mathrm{P}_{\mathrm{N}} / \mathrm{c}_{\mathrm{i}}\right)(n=6)$, maximum photochemical efficiency of dark-adapted leaves $\left(\mathrm{F}_{\mathrm{v}} / \mathrm{F}_{\mathrm{m}}\right)(n=6)$, maximum photochemical efficiency of light-adapted leaves $\left(\Delta \mathrm{F} / \mathrm{F}_{\mathrm{m}}{ }^{\prime}\right)$ and non-photochemical quenching (NPQ) of red and green leaves of mutant and control plants under $1500 \mu \mathrm{mol} \mathrm{m}^{-2} \mathrm{~s}^{-1}$. Means $\pm \mathrm{SD}$. Different letters indicate significant differences $(P<0.01)$.

\begin{tabular}{|c|c|c|c|c|c|}
\hline Parameters & & 10-d-old & 25-d-old & 40-d-old & 55-d-old \\
\hline \multirow{2}{*}{$\begin{array}{l}\text { Anthocyanin content } \\
{\left[\mathrm{mg} \mathrm{g}^{-1} \text { (f.m.) }\right]}\end{array}$} & green leaves & $0.598 \pm 0.100 \mathrm{~b}$ & $0.638 \pm 0.096 b$ & $0.644 \pm 0.082 b$ & $0.645 \pm 0.087 b$ \\
\hline & red leaves & $1.631 \pm 0.079 a$ & $1.049 \pm 0.080 \mathrm{a}$ & $0.860 \pm 0.088 \mathrm{a}$ & $0.822 \pm 0.099 a$ \\
\hline \multirow{2}{*}{$\begin{array}{l}\text { Leaf area } \\
{\left[\mathrm{mm}^{2}\right]}\end{array}$} & green leaves & $4135 \pm 357 b$ & $5302 \pm 428 b$ & $6360 \pm 678 b$ & $6500 \pm 726 b$ \\
\hline & red leaves & $5637 \pm 469 a$ & $6558 \pm 556 a$ & $7800 \pm 430 \mathrm{a}$ & $7850 \pm 680 b$ \\
\hline \multirow{2}{*}{$\begin{array}{l}\text { Leaf thickness } \\
{[\mathrm{mm}]}\end{array}$} & green leaves & $0.218 \pm 0.005 a$ & $0.228 \pm 0.006 a$ & $0.231 \pm 0.012 \mathrm{a}$ & $0.233 \pm 0.009 a$ \\
\hline & red leaves & $0.198 \pm 0.002 b$ & $0.204 \pm 0.006 b$ & $0.214 \pm 0.007 \mathrm{a}$ & $0.218 \pm 0.014 a$ \\
\hline \multirow{2}{*}{$\begin{array}{l}\text { LMA } \\
{\left[\mathrm{mg} \mathrm{cm}^{-2}\right]}\end{array}$} & green leaves & $6.560 \pm 0.059 a$ & $7.450 \pm 0.167 \mathrm{a}$ & $7.895 \pm 0.226 \mathrm{a}$ & $7.900 \pm 0.247 \mathrm{a}$ \\
\hline & red leaves & $4.950 \pm 0.168 b$ & $6.710 \pm 0.106 b$ & $7.400 \pm 0.213 a$ & $7.535 \pm 0.163 a$ \\
\hline \multirow{2}{*}{$\begin{array}{l}\text { Chl } a+b \text { content } \\
{\left[\mathrm{mg} \mathrm{g}^{-1} \text { (f.m.) }\right]}\end{array}$} & green leaves & $2.048 \pm 0.034 \mathrm{a}$ & $2.900 \pm 0.136 \mathrm{a}$ & $2.932 \pm 0.099 a$ & $3.182 \pm 0.056 \mathrm{a}$ \\
\hline & red leaves & $1.550 \pm 0.237 b$ & $2.329 \pm 0.117 b$ & $2.561 \pm 0.031 b$ & $2.981 \pm 0.064 b$ \\
\hline \multirow[t]{2}{*}{ Chl $a / b$} & green leaves & $3.771 \pm 0.197 b$ & $3.589 \pm 0.224 b$ & $3.513 \pm 0.233 b$ & $3.510 \pm 0.243 b$ \\
\hline & red leaves & $4.281 \pm 0.108 \mathrm{a}$ & $3.494 \pm 0.133 b$ & $3.380 \pm 0.009 b$ & $3.360 \pm 0.080 b$ \\
\hline \multirow{2}{*}{ 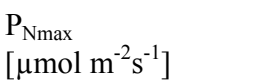 } & green leaves & $23.07 \pm 0.545 \mathrm{a}$ & $25.08 \pm 0.665 \mathrm{a}$ & $26.86 \pm 0.422 \mathrm{a}$ & $26.87 \pm 0.854 a$ \\
\hline & red leaves & $17.78 \pm 1.121 b$ & $20.09 \pm 1.488 b$ & $26.10 \pm 0.528 \mathrm{a}$ & $26.22 \pm 0.750 \mathrm{a}$ \\
\hline \multirow{2}{*}{$\begin{array}{l}\mathrm{P}_{\mathrm{N}} / \mathrm{c}_{\mathrm{i}} \\
{\left[\mathrm{mol} \mathrm{m} \mathrm{m}^{-2} \mathrm{~s}^{-1}\right]}\end{array}$} & green leaves & $0.080 \pm 0.006 \mathrm{a}$ & $0.104 \pm 0.021 \mathrm{a}$ & $0.105 \pm 0.007 \mathrm{a}$ & $0.108 \pm 0.010 \mathrm{a}$ \\
\hline & red leaves & $0.066 \pm 0.008 b$ & $0.080 \pm 0.008 b$ & $0.100 \pm 0.009 \mathrm{a}$ & $0.101 \pm 0.014 \mathrm{a}$ \\
\hline \multirow[t]{2}{*}{$\mathrm{F}_{\mathrm{v}} / \mathrm{F}_{\mathrm{m}}$} & green leaves & $0.822 \pm 0.005 \mathrm{a}$ & $0.836 \pm 0.002 \mathrm{a}$ & $0.851 \pm 0.004 \mathrm{a}$ & $0.850 \pm 0.005 \mathrm{a}$ \\
\hline & red leaves & $0.801 \pm 0.002 b$ & $0.831 \pm 0.002 \mathrm{a}$ & $0.848 \pm 0.006 \mathrm{a}$ & $0.847 \pm 0.005 a$ \\
\hline \multirow[t]{2}{*}{$\Delta \mathrm{F} / \mathrm{F}_{\mathrm{m}}{ }^{\prime}$} & green leaves & $0.410 \pm 0.006 b$ & $0.474 \pm 0.014 \mathrm{a}$ & $0.509 \pm 0.007 \mathrm{a}$ & $0.538 \pm 0.007 \mathrm{a}$ \\
\hline & red leaves & $0.454 \pm 0.201 \mathrm{a}$ & $0.420 \pm 0.016 b$ & $0.482 \pm 0.007 b$ & $0.513 \pm 0.007 b$ \\
\hline \multirow[t]{2}{*}{ NPQ } & green leaves & $2.335 \pm 0.676 b$ & $2.524 \pm 0.084 b$ & $2.807 \pm 0.171 b$ & $2.972 \pm 0.170 b$ \\
\hline & red leaves & $2.768 \pm 0.109 a$ & $2.974 \pm 0.410 \mathrm{a}$ & $3.294 \pm 0.113 \mathrm{a}$ & $3.494 \pm 0.133 a$ \\
\hline
\end{tabular}

Red leaf area was considerably larger than green leaf area during the initial development stage; green leaf thickness and LMA were considerably greater than in red leaves during the first and second stage. Maksymowych (1973) observed that initial leaf thickness is established during early leaf development following a phase of rapid thickening. Thicker leaves allow a greater photosynthetic apparatus per unit leaf area while broader, thinner leaves can intercept more photosynthetically active radiation (PAR; White et al. 2005). This may be the cause why red leaves had larger overall leaf area compared to green leaves.

Leaf Chl content increased in conjunction with an increase in leaf area, and it was considerably higher in green leaves as compared to red leaves (Table 1). Similar pattern of $\mathrm{Chl}$ content have also been reported for developing leaves of Rosa sp. and Ricinus communis where leaves with high anthocyanin contents had up to $50 \%$ greater $\mathrm{Chl}$ content compared to mature leaves (Manetas et al. 2002). Merzlyak (2008) also observed that leaves with anthocyanins contained low Chl content. During leaf development, young leaves require high photodissipative capacity (Krause et al. 1995). Therefore, young red leaves containing low $\mathrm{Chl}$ and high anthocyanin contents can alleviate these requirements due to lessened Chl excitation pressure (Manetas et al. 2002).
With regard to the mutant of $F$. dibotrys that contained low Chl content and thin leaves, this may be the result of an adaptive mechanism triggered by excessive sunlight $\left(>1200 \mu \mathrm{mol} \mathrm{m} \mathrm{m}^{-2} \mathrm{~s}^{-1}\right.$. Larger red leaf area in comparison to green leaf area may be the result of competition of anthocyanins with $\mathrm{Chl}$ for light absorption (Merzlyak et al. 2008). Red leaf area spread may therefore be the result of compensative adaptation to capture greater amounts of sunlight.

The visible anthocyanin of red leaves dramatically decreases while Chl increases during development, but Chl content and leaf LMA and thickness were still lower in red leaves than in green leaves. The red leaves growth was probably retarded by the anthocyanin accumulation (Jones 1995, Hopkins and Hüner 2004).

Anthocyanins always absorb blue to green to yellow radiation, therefore, higher anthocyanins accumulation in red leaves essentially eliminate the radiation absorbed by chlorophyll and so provide protection against photoinhibition especially in young leaves (Manetas 2006).

The lower $\mathrm{Chl} a / b$ ratio in red leaves than in green leaves indicates decrease in core complex (exclusively $\mathrm{Chl} a$ ) relative to the light-harvesting (both $\mathrm{Chl} a$ and Chl b) complex (Hopkins and Hüner 2004).

The $\mathrm{P}_{\mathrm{Nmax}}$ and apparent carboxylation efficiency were higher in green leaves compared to red leaves during leaf 
development (Table 1). Previous study showed that red leaves possessed a lower area-based photosynthetic rate, apparent carboxylation efficiency, and LMA than green leaves due to shade acclimation (Lichtenthaler et al. 2000). The red mutant of $F$. dibotrys was partly consistent with these characteristics. Moreover, anthocyanins retarded leaf growth and compete with Chl for light. This is consistent with lower LMA, thickness, and photosynthetic rates in red leaves throughout development.

Our results suggested that photoinhibition did not take place in either red or green leaves because $F_{v} / F_{m}$ remained approximately 0.8 at all times (Table 1) while it increased during leaf development as in European beach (Čaňová et al. 2008). The $\mathrm{F}_{\mathrm{v}} / \mathrm{F}_{\mathrm{m}}$ in red leaves was slightly lower than in green ones. The phenomenon was also found in red leaves of Prunus cerasifera, which possessed slightly lower $\mathrm{F}_{\mathrm{v}} / \mathrm{F}_{\mathrm{m}}$ values compared to green leaves (Kyparissis et al. 2007). Leaf $\Delta \mathrm{F} / \mathrm{F}_{\mathrm{m}}{ }^{\prime}$ values were higher in red than in green leaves during the first stage but they decreased during succeeding stages, indicating that a portion of light absorbed by anthocyanins in red leaves was not used in photosynthesis (Table 1). This is

\section{References}

Ambasht, N.K., Agrawal, M.: Effects of enhanced UV-B radiation and tropospheric ozone on physiological and biochemical characteristics of field grown wheat. - Biol. Plant. 47: 625-628, 2003.

Cai, Z.-Q., Slot, M., Fan, Z.-X.: Leaf development and photosynthetic properties of three tropical tree species with delayed greening. - Photosynthetica 43: 91-98, 2005.

Čaňová, I., Duurkovič, J., Hladká, D.: Stomatal and chlorophyll fluorescence characteristics in European beech cultivars during leaf development. - Biol. Plant. 52: 577-581, 2008.

Chalker-Scott, L.: Environmental significance of anthocyanins in plant stress response. - Photochem. Photobiol. 70: 1-9, 1999.

Coley, P.D., Kursar, T.A.: Anti-herbivore defenses of young tropical leaves: physiological constraints and ecological tradeoffs. - In: Mulkey, S.S., Chazdon, R., Smith, A.P. (ed.): Tropical Forest Plant Ecophysiology. Pp. 305-336. Chapman and Hall, New York 1996.

Dominy, N.J., Lucas, P.W., Ramsden, L., Riba-Hernandez, P., Stoner, K.E., Turner, I.M.: Why are young leaves red? Oikos 98: 163-176, 2002.

Feild, T.S., Lee, D.W., Holbrook, N.M.: Why leaves turn red in autumn: the role of anthocyanins in senescing leaves of redosier dogwood. - Plant Physiol. 127:566-574, 2001.

Genty, B., Briantais, J.M., Baker, N.R.: The relationship between the quantum yield of photosynthetic electrontransport and quenching of chlorophyll fluorescence. Biochim. biophys. Acta 990: 87-92, 1989.

Hipskind, J., Wood, K., Nicholson, R.L.: Localized stimulation of anthocyanin accumulation and delineation of pathogen ingress in maize genetically resistant to Bipolaris maydis race O. - Physiol. mol. Plant Pathol. 49: 247-256, 1996.

Hopkins, W.G., Hüner, N.P.A.: Photosynthetic electron transport. - In: Hopkins, W.G., Hüner, N.P. (ed.): consistent with the low $\mathrm{P}_{\mathrm{N}}$. Based on previous reports (Merzlyak et al. 2008) anthocyanins accumulated in red leaves possessed a protective function during leaf development. Certain studies have also shown high amounts of anthocyanins in young red leaves of Anthocephalus chinensis and Litsea pierrei possessing low diurnal photoinhibition (Cai et al. 2005).

NPQ increased gradually for both leaf types during development (Table 1). However, NPQ was higher in red than in green leaves, which reveals that red leaves dissipated a greater amount of light energy as heat than green leaves in order to protect the photosynthetic apparatus. Also previous study showed that red leaf NPQ was higher compared to green leaf NPQ (Li et al. 2009).

In conclusion, red leaves with greater anthocyanin accumulation below the upper leaf surface likely impose a limitation to leaf development but possess a photoprotection capacity. Further research is required to elucidate the intrinsic mechanism of anthocyanin accumulation and the photosynthetic properties of F. dibotrys mutant.
Introduction to Plant Physiology. Pp. 68-71. John Wiley, New York 2004.

Hughes, N.M., Smith, W.K.: Attenuation of incident light in Galax urceolata (Diapensiaceae): concerted influence of adaxial and abaxial anthocyanic layers on photoprotection. Amer. J. Bot. 94: 784-790, 2007.

Janda, T., Szalai, G., Paldi, E.: Chlorophyll fluorescence and anthocyanin content in chilled maize plants after return to a non-chilling temperature under various irradiances. - Biol. Plant. 38: 625-627, 1996.

Jones, C.S.: Does shade prolong juvenile leaf development? A morphological analysis of leaf shape changes in Cucurbita argyrosperma subsp. sororia (Cucurbitaceae). - Amer. J. Bot. 82: 346-359, 1995.

Krol, M., Gray, G.R., Hurry, V.M., Oquist, G., Malek, L., Huner, N.P.A: Low-temperature stress and photoperiod affect an increased tolerance to photoinhibition in Pinus banksiana seedlings. - Can. J. Bot. 73: 1119-1127, 1995.

Kumar, P., Sharma, S.D.: Nutrient deficiency-dependent anthocyanin development in Spirodela polyrhiza L. Schleid. -Biol. Plant. 42: 621-624, 1999.

Krause, G.H., Virgo, A, Winter, K.: High susceptibility to photoinhibition of young leaves of tropical forest trees. Planta 197: 583-591, 1995.

Kursar, T.A., Coley, P.D.: Delayed greening in tropical leaves: an antiherbivore defense? - Biotropica 24: 256-262, 1992.

Kyparissis, A., Grammatikopoulos, G., Manetas, Y.: Leaf morphological and physiological adjustments to the spectrally selective shade imposed by anthocyanins in Prunus cerasifera. - Tree Physiol. 27: 849-857, 2007.

Kytridis, V.-P., Karageorgou, P., Levizou, E., Manetas, Y.: Intraspecies variation in transient accumulation of leaf anthocyanins in Cistus creticus during winter: evidence that anthocyanins may compensate for an inherent 


\section{J.-X. LAN et al.}

photosynthetic and photoprotective inferiority of the redleaf phenotype. - J. Plant Physiol. 165: 952-959, 2008.

Lambers, H., Chapin III, F.S., Pons, T.L.: Plant Physiological Ecology. - Springer-Verlag, Berlin - New York 1998.

Li, P.-M., Cheng, L., Peng, T., Gao, H.-Y.: $\mathrm{CO}_{2}$ assimilation and chlorophyll fluorescence in green versus red Berberis thunbergii leaves measured with different quality irradiation. - Photosynthetica 47: 11-18, 2009.

Lichtenthaler, H.K.: Chlorophylls and carotenoids: pigments of photosynthetic biomembranes. - Methods Enzymol. 148: 350-382, 1987.

Lichtenthaler, H.K., Babani, F., Langsdorf, G., Buschmann, C.: Measurement of differences in red chlorophyll fluorescence and photosynthetic activity between sun and shade leaves by fluorescence imaging. - Photosynthetica 38: 521-529, 2000.

Maksymowych, R.: Analysis of Leaf Development. Cambridge University Press, Cambridge 1973.

Manetas, Y.: Why some leaves are anthocyanic and why most anthocyanic leaves are red? - Flora 201:163-177. 2006.

Manetas, Y., Drinia, A., Petropoulou, Y.: High contents of anthocyanins in young leaves are correlated with low pools of xanthophyll cycle components and low risk of photoinhibition. - Photosynthetica 40: 349-354, 2002.

Manetas, Y., Petropoulou, Y., Psaras, G.K., Drinia, A.: Exposed red (anthocyanic) leaves of Quercus coccifera display shade characteristics. - Funct. Plant Biol. 30: 265-270, 2003.

Merzlyak, M.N., Chivkunova, O.B., Solovchenko, A.E., Naqvi, K.R.: Light absorption by anthocyanins in juvenile, stressed, and senescing leaves. - J. exp. Bot. 59: 3903-3911, 2008.

Murray, J.R., Hackett, W.P.: Dihydroflavonol reductase activity in relation to differential anthocyanin accumulation in juvenile and mature phase Hedera helix L. - Plant Physiol. 97: 343-351, 1991.

Numata, S., Kachi, N., Okuda T., Manokaran, N.: Delayed greening, leaf expansion, and damage to sympatric Shorea species in a lowland rain forest. - J. Plant Res. 117: 19-25, 2004.

Pomar, F., Barceló, A.R.: Are red leaves photosynthetically active? - Biol. Plant. 51: 799-800, 2007.

Prado, C.R.B.A., Moraes, J.A.P.V. DE.: Photosynthetic capacity and specific leaf mass in twenty woody species of Cerrado vegetation under field conditions. - Photosynthetica 33: 103-112, 1997.

Ravindran, K.C., Maheskumar, N., Amirthalingam, V., Ranganathan, R., Chellappan, K.P., Kulandaivelu, G.: Influence of UV-B supplemental radiation on growth and pigment content in Suaeda maritime L. - Biol. Plant. 44: 467-469, 2001.

Stone, C., Chisholm, L., Coops, N.: Spectral reflectance characteristics of eucalypt foliage damaged by insects. Aust. J. Bot. 49: 87-98, 2001.

Ulrychová, M., Sosnová, V.: Effect of phosphorus deficiency on anthocyanin content in tomato plants. - Biol. Plant. 12: 231235, 1970.

White, J.W., Montes-R, C.: Variation in parameters related to leaf thickness in common bean (Phaseolus vulgaris L.). Field Crops Res. 91: 7-21, 2005. 